\title{
An Alternative Approach to the Fracture Toughness of Dual Phase Steels
}

\author{
S. Ulu, ${ }^{\mathrm{a}, 1}$ H. Aytekin, ${ }^{\mathrm{a}}$ and G. Said ${ }^{\mathrm{b}}$ \\ ${ }^{a}$ Afyon Kocatepe University, Afyonkarahisar, Turkey \\ ${ }^{\mathrm{b}}$ Bartin University, Bartin, Turkey \\ ${ }^{1}$ sinanulu@aku.edu.tr
}

УДК 539.4

\section{Альтернативный подход к оценке вязкости разрушения двухфазных сталей}

\author{
С. Улуа \\ а Афьон Коджатепе университет, Афьонкарахисар, Турция \\ ${ }^{\sigma}$ Университет г. Бартын, Турция
}

\begin{abstract}
Исследуется влияние морфологии структуры феррита и его объемного содержания на механические свойства и вязкость разрушения двухфазных сталей. Для определения значений вязкости разрушения использовали не стандартный, а альтернативный подход. Стали подвергали гомогенизирующей термообработке. Путем полного отжсиа или закалки сталей из аустенитного состояния до применения докритического отжига в аустенитной области получены две различные исходные микроструктуры. Получены двухфазные стали с двумя типами морфологии (крупно- и мелкозернистая) с 40-, 20- и 10\%-ным объемным содержанием феррита в зависимости от исходной микроструктуры. Отпущенные образцьл с 10\%-ным объемным содержанием феррита имели более высокие значения вязкости разрушения по сравнению с таковыми других образцов из этих сталей.
\end{abstract}

Ключевые слова: двухфазные стали, объемное содержание феррита, механические свойства, вязкость разрушения.

\section{Notation}

$\sigma_{\max }-$ tensile strength, MPa

$\sigma_{y} \quad-$ yield stress, MPa

$S_{\text {rup }}-$ rupture stress, $\mathrm{MPa}$

$S_{\text {frac }}$ - fracture stress without plastic deformation, MPa

$\psi \quad-$ reduction in area, $\%$

$\delta \quad-$ elongation, $\%$

$T_{z p} \quad-$ zero plasticity temperature, $\mathrm{K}$

$T_{\text {melt }}-$ melting temperature, $\mathrm{K}$

$\dot{\varepsilon} \quad-$ strain rate, $\mathrm{s}^{-1}$

$\dot{\varepsilon}_{c r} \quad-$ critical strain rate, $\mathrm{s}^{-1}$

$\sigma_{y 0}-$ value of yield stress at $T_{0}=293 \mathrm{~K}, \mathrm{MPa}$ 


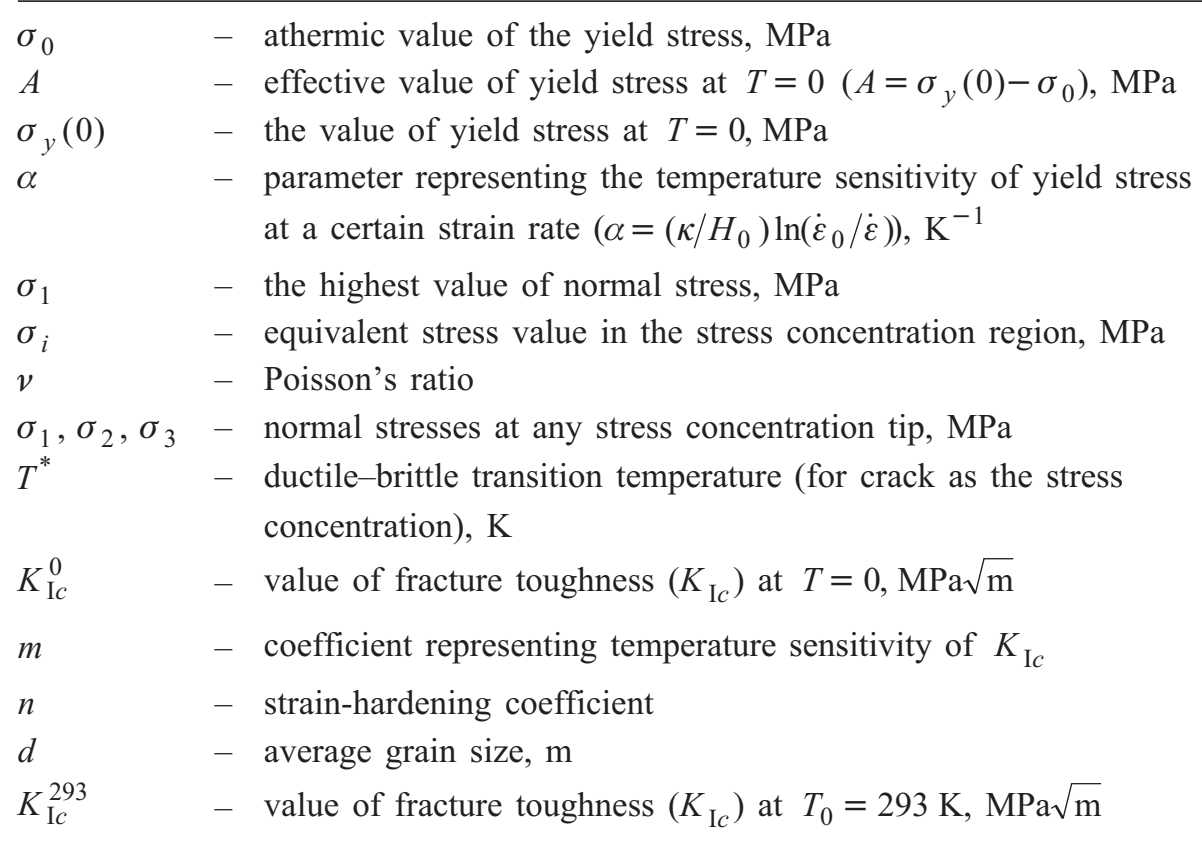

Introduction. Dual phase steels contain small amounts of retained austenite and bainite phases and between 10 and 30\% hard martensite particles in the ferrite matrix that has ductile and small grains [1]. The term "dual phase" indicates the coexistence of phases that exhibit opposite properties. A dual phase steel structure can be obtained by heating low-alloy hypoeutectoid steels at temperatures between the $A c_{1}$ and $A c_{3}$ temperatures.

The microstructures of conventional carbon steels are usually not suitable for plastic deformation when the amount of carbon is increased because plastic deformation compromises the strengths of the steels. However, the plasticity and strength properties of dual phase steels can be optimized, and these properties can be tailored over a wide range by using heat treatments [2].

A literature search on the fracture toughness of dual phase steels reveals that there is a limited number of studies on this subject $[3,4]$.

The ASTM-E399 standard has been developed for the determination of the fracture toughness of metallic materials [5]. However, to determine the fracture toughness of steels that have a bcc lattice structure, the experiment should be conducted on large-scale specimens (to obey the condition of planar deformation), according to this standard. This requirement makes it difficult to conduct the experiment; the necessity of preparing large-scale specimens and the difficulty of achieving a dual phase structure in the specimens have limited the number of studies that have been conducted on the fracture toughness $\left(K_{\mathrm{I} c}\right)$ of dual phase steels.

SAE1020 steel was used in this study. First, a homogenization treatment was applied to the steel at $1150^{\circ} \mathrm{C}$ for 12 hours. Then, Group 1 specimens were subjected to full annealing, while Group 2 specimens were subjected to quenching from the austenite zone. Thus, the steels had two different starting microstructures. The specimens from both groups were then annealed at intercritical temperatures $\left(720,730,740,750,760,770,780,790,800\right.$, and $\left.810^{\circ} \mathrm{C}\right)$. The microstructures 
were analyzed using the MicroCAM 1.4 software, and the phase volume fractions and the average grain sizes were calculated. The heat treatment parameters that were common to both groups were identified. Additionally, tempering was applied to the specimens that had these common heat treatment parameters. After the heat treatment, mechanical tests were conducted. Fracture toughness $\left(K_{\mathrm{I} c}\right)$ calculations were performed that were based on the tensile test results. The process steps that were used in this study are listed below:

\begin{tabular}{|l|l|l|}
\hline $\begin{array}{l}\text { Homogenization at } 1150^{\circ} \mathrm{C} \text { for } 12 \text { hours } \\
\text { (for all of the specimens) }\end{array}$ \\
$\begin{array}{l}\text { 1) Full annealing } \\
\text { 3) Calculation of the ferrite volume fraction } \\
\text { 4) Determination of the heat treatment } \\
\text { temperatures of } 40 \%, 20 \% \text { and } 10 \% \text { ferrite }\end{array}$ & $\begin{array}{l}\text { 3) Calculation of the ferrite volume fraction } \\
\text { 4) Determination of the heat treatment } \\
\text { temperatures of } 40 \%, 20 \% \text { and } 10 \% \text { ferrite }\end{array}$ \\
\hline $\begin{array}{l}\text { 5.1) Mechanical test of } \\
\text { the specimens made } \\
\text { using the heat treatment } \\
\text { parameters identified in } \\
\text { process step } 4\end{array}$ & $\begin{array}{l}\text { 5.2) Mechanical test of the } \\
\text { specimens tempered at } 650^{\circ} \mathrm{C} \\
\text { and made using the heat } \\
\text { treatment parameters } \\
\text { identified in process step } 4\end{array}$ & $\begin{array}{l}\text { 5.1) Mechanical test of } \\
\text { the specimens made } \\
\text { using the heat treatment } \\
\text { parameters identified in } \\
\text { process step } 4\end{array}$ \\
\hline
\end{tabular}

\section{Materials and Methods.}

1.1. Materials. The chemical composition of the steel used in this study is given in Table 1.

$\mathrm{T}$ a b 1 e 1

Chemical Composition of SAE1020 Steel (wt.\%)

\begin{tabular}{||c|c|c|c|c|c|c|c|c||}
\hline \hline Steel & $\mathrm{C}$ & $\mathrm{Si}$ & $\mathrm{Mn}$ & $\mathrm{P}$ & $\mathrm{S}$ & $\mathrm{Cr}$ & $\mathrm{Mo}$ & $\mathrm{Ni}$ \\
\hline \multirow{3}{*}{ SAE1020 } & 0.212 & 0.198 & 0.486 & 0.036 & 0.032 & 0.053 & 0.052 & 0.089 \\
\cline { 2 - 9 } & $\mathrm{Al}$ & $\mathrm{B}$ & $\mathrm{Cu}$ & $\mathrm{Nb}$ & $\mathrm{Ti}$ & $\mathrm{W}$ & \multicolumn{2}{|c||}{$\mathrm{Fe}$} \\
\cline { 2 - 9 } & 0.003 & 0.016 & 0.183 & 0.032 & 0.006 & 0.004 & \multicolumn{2}{|c|}{ Balance } \\
\hline
\end{tabular}

1.2. Heat Treatment. In this study, a $1200^{\circ} \mathrm{C}$ heat treatment furnace was used for the heat treatment. A chromel-alumel thermocouple was spot-welded to the centre of one of the faces of the specimen to maintain the correct temperature during the heat treatment. For the heat treatment, water with a $10 \%$ salt concentration was used as the quenching media. Andrews' empirical formulas, given below, were used to determine the full annealing and quenching temperatures [6]

$$
\begin{aligned}
& A c_{1}=723-20.7 \mathrm{Mn}-6.9 \mathrm{Ni}+29.1 \mathrm{Si}+16.9 \mathrm{Cr}+290 \mathrm{As}+6.38 \mathrm{~W}, \\
& A c_{3}=910-203 \mathrm{C}^{1 / 2}-15.2 \mathrm{Ni}+44.7 \mathrm{Si}+104 \mathrm{~V}+31.5 \mathrm{Mo}+13.1 \mathrm{~W}
\end{aligned}
$$

The $A c_{1}$ and $A c_{3}$ temperatures of the steel, which were determined from formulas (1) and (2), are given in Table 2. 
$\mathrm{T}$ a b 1 e 2

Critical Temperatures $\left({ }^{\circ} \mathrm{C}\right)$ of SAE1020 Steel

\begin{tabular}{|c|c|c|}
\hline Steel & $A c_{1}$ & $A c_{3}$ \\
\hline SAE1020 & 719 & 897 \\
\hline
\end{tabular}

1.3. Tensile Test. A SHIMADZU uniaxial tensile test machine with a capacity of 10 tons was used for tensile tests. The dimensions of the specimens that were used in the experiment are shown in Fig. 1 [7].

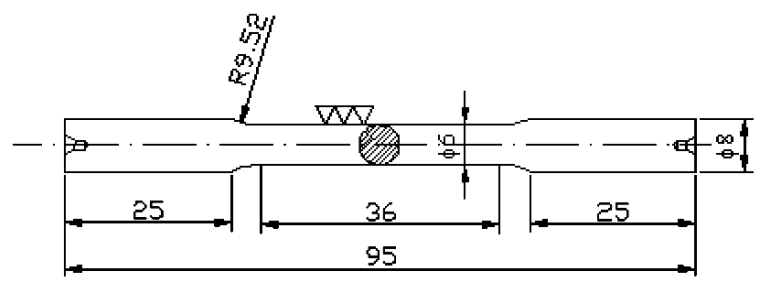

Fig. 1. Tensile test specimen measurements with single axis [7].

1.4. Fracture Toughness. An approach was used to determine the fracture toughness of the specimens that eliminated the use of cracked specimens and that related the fracture toughness parameters to other mechanical properties. The purpose of the developed approach was to reveal the connection between the fracture toughness $\left(K_{\mathrm{I} c}\right)$ parameters of ferritic steels (with bcc structures) and the other mechanical properties of the steels by taking into account the microfracture mechanisms of the materials. The principles of this method are given below, and the fields in which it can be applied are as follows [8]: (i) for bcc metals and alloys; (ii) over the temperature range $0 \leq T \leq 0.2 T_{\text {melt }}(\mathrm{K})$; (iii) for strain rates $\dot{\varepsilon} \leq \dot{\varepsilon}_{c r}$.

1.4.1. Temperature Relation of the Fundamental Mechanical Properties of Ferritic Steels. The ideas covered in this section attempt to explain the changes in the yield strength of bcc metals and alloys with varying temperature. The changes in the basic mechanical properties $\left(\sigma_{y}, \sigma_{\max }, S_{\text {rup }}, S_{\text {frac }}\right.$, and $\left.\psi\right)$ of these metals and alloys with varying temperature are shown in Fig. 2 [8].

1.4.1.1. Makhutov Approach. A graph of the yield stress variation with varying temperature can be obtained by using the results of a single experiment conducted at room temperature. To obtain this graph, a formula that was proposed by Makhutov was used [9]:

$$
\sigma_{y(T)}=\sigma_{y 0} \exp \left[\beta_{y}\left(\frac{1}{T}-\frac{1}{T_{0}}\right)\right] .
$$

The relation between $\beta_{y}$ and $\sigma_{y 0}$ is shown in Fig. 3 [9].

1.4.1.2. Yaroshevich Approach. Based on "a movement model based on dual bending of dislocations," a formula was derived by Yaroshevich in the 1970s that takes into account the dependence of the yield stress on temperature and on the strain rate [10]: 


$$
\sigma_{y}=\sigma_{0}+A e^{-\alpha T}
$$

Formula (4) specifies the dependence of the yield stress on the strain rate $(\dot{\varepsilon})$ and on temperature $(T)$. As the strain rate increases, $\alpha$ decreases, while $\sigma_{y}$ increases.

Formula (3) can be used to determine the parameters $\sigma_{0}, A$, and $\alpha$ that are used in formula (4). To obtain these parameters, the $\sigma_{y}$ values were calculated for various temperatures (e.g., 150, 200, and $250^{\circ} \mathrm{C}$ ) using formula (3).

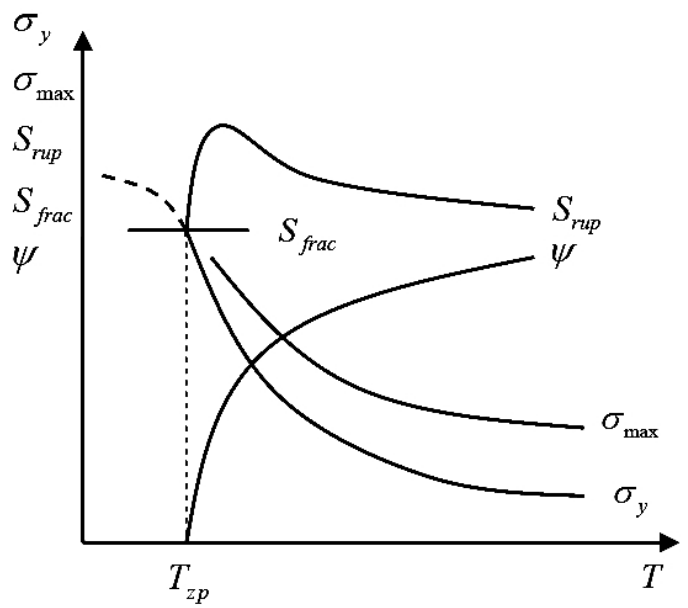

Fig. 2. Change with temperature of fundamental mechanical properties (schematically).

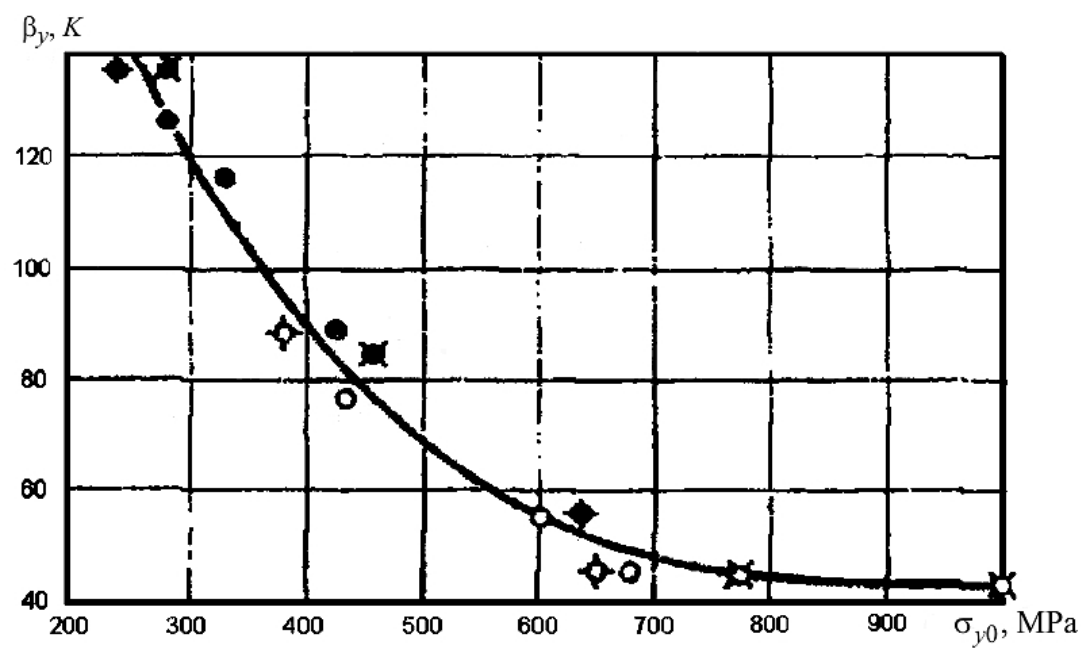

Fig. 3. Relation of $\beta_{y}$ with yield strength.

The $\sigma_{0}, A$, and $\alpha$ parameters can be expressed by the following formulas:

$$
\sigma_{0}=\frac{\sigma_{2}^{2}-\sigma_{1} \sigma_{3}}{2 \sigma_{2}-\left(\sigma_{1}+\sigma_{3}\right)}
$$




$$
\begin{gathered}
\alpha=\frac{1}{\Delta T} \ln \left(\frac{\sigma_{1}-\sigma_{0}}{\sigma_{2}-\sigma_{0}}\right), \\
A=\left(\sigma_{1}-\sigma_{0}\right) e^{\alpha T_{1}}=\left(\sigma_{2}-\sigma_{0}\right) e^{\alpha T_{2}}=\left(\sigma_{3}-\sigma_{0}\right) e^{\alpha T_{3}} .
\end{gathered}
$$

The temperature at which a cylindrical specimen has zero plasticity, $T^{*}=T_{z p}$ $\left(\sigma_{y}=\sigma_{\max }=S_{\text {rup }}\right)$, is given by

$$
T^{*}=\left[\frac{1}{T_{0}}+\frac{1}{\beta_{y}} \ln \left(\frac{S_{r u p}}{\sigma_{y 0}}\right)\right]^{-1} .
$$

The $S_{\text {frac }}$ value can be determined by substituting $T^{*}$ into formula (4).

1.4.2. Brittle Fracture Condition of Metals and Alloys. The following two conditions need to be met for the brittle fracture of metals and alloys to occur [11]:

$$
\begin{gathered}
\sigma_{1} \geq S_{\text {frac }}, \\
\sigma_{i} \geq \sigma_{y} .
\end{gathered}
$$

In accordance with the condition that $\sigma_{y}=\sigma_{\max }=S_{\text {rup }}(\psi=0)$, the brittle fracture stress $\left(S_{\text {frac }}\right)$ corresponds to the resistance of the material to brittle fracture (Fig. 1). The $S_{\text {frac }}$ parameter is not dependent on temperature, the deformation rate, or the stress concentration; $S_{\text {frac }}$ only depends on the grain size of the material.

Taking into account the fact that brittle fracture occurs at a specific temperature $\left(T=T_{z p}\right)$ (and that $\sigma_{i}=\sigma_{1}, \sigma_{2}=0$, and $\sigma_{3}=0$ for the uniaxial tensile test of cylindrical specimens), using formula (9) we obtain

$$
\varphi=\frac{\sigma_{1}}{\sigma_{i}}=\left.\frac{S_{f r a c}}{\sigma_{y}}\right|_{T=T_{z p}} .
$$

The von Mises criteria can be used to find the equivalent stress $\left(\sigma_{i}\right)$

$$
\sigma_{i}=\frac{1}{\sqrt{2}} \sqrt{\left(\sigma_{1}-\sigma_{2}\right)^{2}+\left(\sigma_{2}-\sigma_{3}\right)^{2}+\left(\sigma_{3}-\sigma_{1}\right)^{2}} .
$$

Since the fracture toughness $\left(K_{\mathrm{I} c}\right)$ takes into account the planar deformation condition of the crack tip (brittle fracture), the $\sigma_{1} / \sigma_{i}$ ratio in formula (10) needs to be determined. The $\sigma_{i}$ value in this ratio can be evaluated using formula (11). The principal stresses under planar strain conditions are

$$
\sigma_{1}=\sigma_{2}, \quad \sigma_{3}=2 v \sigma_{1}=2 v \sigma_{2}
$$


If these values are substituted into formula (11), we obtain

$$
\frac{\sigma_{1}}{\sigma_{i}}=\frac{1}{1-2 v}
$$

If $v=0.3$ for the steels under study,

$$
\frac{S_{\text {frac }}}{\sigma_{y}}=\frac{\sigma_{1}}{\sigma_{i}}=2.5 .
$$

The relation between the $S_{\text {frac }} / \sigma_{y}$ ratio in formula (14) and temperature is schematically shown in Fig. 4.

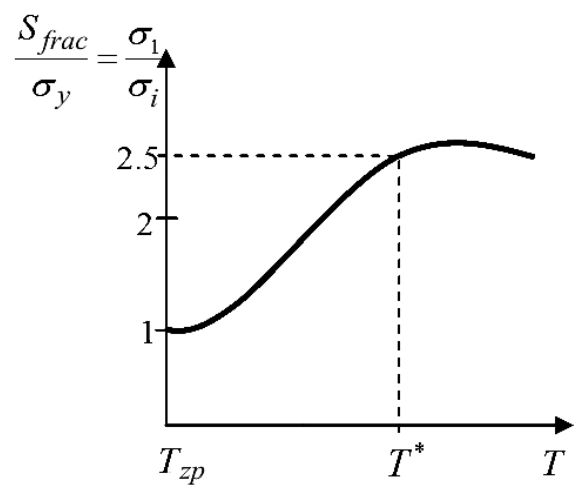

Fig. 4. Variation of $S_{\text {frac }} / \sigma_{y}$ value with temperature (schematically).

1.4.3. Fracture Hypothesis and Micromechanism. A fracture hypothesis has been adopted for ferritic steels (bcc metals and alloys) that is based on the thermal activation energy and on the exponential dependence of the plastic deformation of the fracture toughness at the crack tip [12]. The mathematical formulation of this hypothesis is

$$
K_{\mathrm{I} c}=K_{\mathrm{I} c}^{0} \exp (\alpha m T)
$$

The $K_{\mu}$ fracture model for such steels is based on the formation of microcracks in which the impact of the critical stress $\left(\sigma_{c}\right)$ occurs at a certain distance $\left(\rho_{c}\right)$ from the crack tip. The progress of the main crack is the result of the microcracks that move along the main crack and connect with it (this same process is repeated multiple times). According to this fracture mechanism [13],

$$
\begin{gathered}
\frac{K_{\mathrm{I} c}}{K_{\mu}}=\left(\frac{\sigma_{c}}{\sigma_{y}}\right)^{(1-n) / 2 n}, \\
K_{\mu}=\sigma_{c} \sqrt{\pi \rho_{c}} .
\end{gathered}
$$


The following equations were used for $K_{\mathrm{I} c}$ based on test results [12]

$$
\begin{gathered}
K_{\mu}=K_{\mathrm{I} c}^{0}, \\
\sigma_{c}=\sigma_{y}(0)-\sigma_{0}=A, \\
\rho_{c}=d .
\end{gathered}
$$

Substituting formula (15) into formula (16) and incorporating the above equations, we obtain

$$
\begin{gathered}
\alpha m T=\chi \ln \left(\frac{A}{\sigma_{y}}\right), \\
\chi=\frac{1-n}{2 n} .
\end{gathered}
$$

If $T^{*}$ is substituted into formula (19), after some calculations have been performed, the relation between the fracture toughness and temperature can be expressed by the following formula:

$$
K_{\mathrm{I} c}=K_{\mathrm{I} c}^{0} \exp \left[\frac{T}{T^{*}} \chi^{*} \ln \frac{A}{\sigma_{y}^{*}}\right]=K_{\mathrm{I} c}^{0}\left(\frac{A}{\sigma_{y}^{*}}\right)^{\frac{\chi^{*}}{T^{*}}} .
$$

Given the grain size of the material,

$$
K_{\mathrm{I} c}=A \sqrt{\pi d}\left(\frac{A}{\sigma_{y}^{*}}\right)^{\frac{\chi^{*}}{T^{*}} T} .
$$

According to formula (22), the fracture toughness can be determined by using the mechanical properties that can be obtained from tensile tests and the average grain size $(d)$, which can be determined from the metallographic analysis.

\section{Experimental Results and Comments.}

2.1. Heat Treatment Results and the Microstructure. A metallographic examination revealed that the supplied material had a banded microstructure that consisted of ferrite and pearlite, as shown in Fig. 5a. To remove this banding and to ensure a uniform austenite composition prior to intercritical annealing, the rods were homogenized at $1150^{\circ} \mathrm{C}$ for 12 hours. Figure 5 shows the microstructure obtained after homogenization.

After homogenization, the grain sizes increased and the banded microstructure disappeared. Two different starting microstructures were then obtained by subjecting the specimens to full annealing and to quenching from the austenite zone (Fig. 6a 


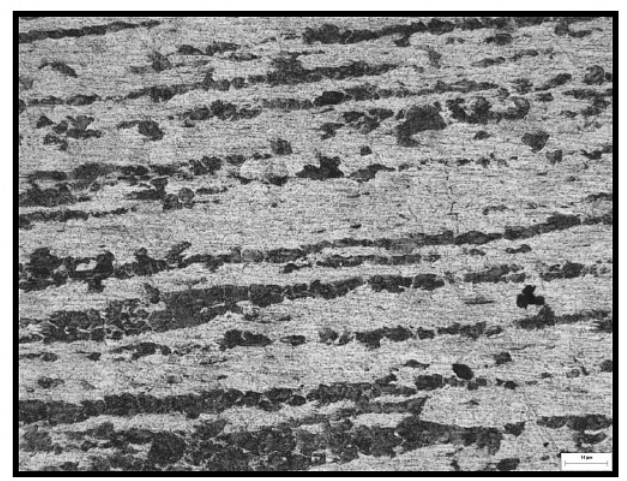

$\mathrm{a}$

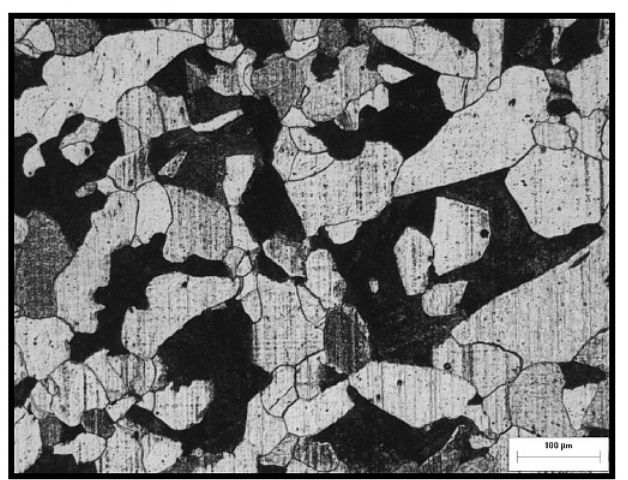

b

Fig. 5. Cross-sectional microstructure of as received SAE 1020 steel (a); cross-sectional microstructure of homogenized SAE 1020 steel (b).

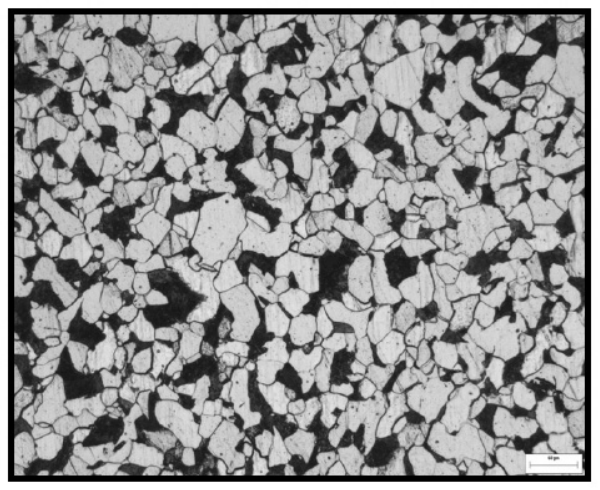

a

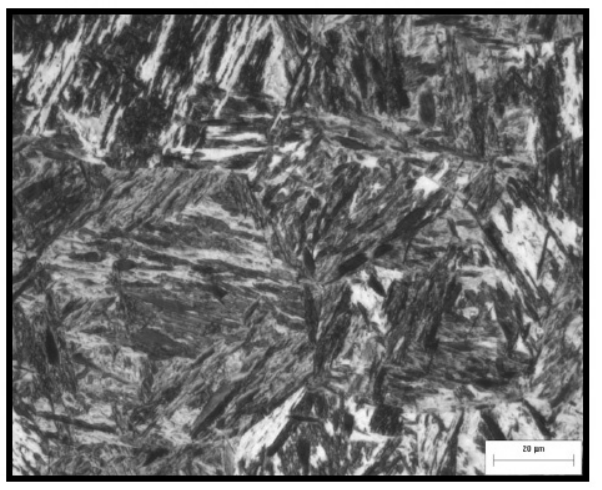

b

Fig. 6. Microstructure of full annealed SAE 1020 steel (a); microstructure of quenched SAE 1020 steels (b).

and $b$ ). The initial microstructure is defined as the microstructure that the steels have before intercritical annealing. The phase morphology, the grain sizes of the phases and the mechanical properties of the dual phase steels depend on the initial microstructure [14-18].

The microstructure after full annealing is composed of ferrite-pearlite, whereas the microstructure after quenching is composed of martensite. After the initial microstructures were obtained, intercritical annealing of the specimens was conducted (at 720, 730, 740, 750, 760, 770, 780, 790, 800, and $810^{\circ} \mathrm{C}$ ).

After the heat treatments, the ferrite-pearlite starting microstructure exhibited coarse-dispersed ferrite-martensite grains, whereas the martensite starting microstructure exhibited fine-dispersed ferrite-martensite grains [14].

The obtained ferrite volume fraction (FVF) results are given in Table 3.

According to the results of the phase volume fractions, as determined from the experiments, the quenching process, which resulted in 40, 20, and 10\% FVFs for both starting microstructures, was chosen (intercritical annealing temperatures of 740,790 , and $800^{\circ} \mathrm{C}$ were used for the ferrite-pearlite and 730,770 , and $790^{\circ} \mathrm{C}$ were used for the martensite structures). These parameters were used for the 
T a b 1 e 3

Ferrite Volume Fractions (\%) Obtained from Intercritical Annealing in Specimens with Ferrite-Pearlite and Martensite of Starting Microstructure

\begin{tabular}{|c|c|c|c|c|c|c|c|c|c|c|c||}
\hline \multirow{2}{*}{ Steel } & \multirow{2}{*}{$\begin{array}{c}\text { Starting } \\
\text { microstructure }\end{array}$} & \multicolumn{10}{|c||}{ Temperature $\left({ }^{\circ} \mathrm{C}\right)$} \\
\cline { 3 - 14 } & 720 & 730 & 740 & 750 & 760 & 770 & 780 & 790 & 800 & 810 \\
\hline \multirow{2}{*}{ SAE1020 } & Ferrite-perlite & 65.4 & 50.5 & 43.1 & 37.8 & 36.3 & 34.1 & 23.8 & 20.7 & 8.1 & - \\
\cline { 2 - 13 } & Martensite & - & 41.0 & 35.1 & 37.9 & 32.9 & 22.9 & 15.7 & 9.8 & 4.5 & 1.1 \\
\hline
\end{tabular}
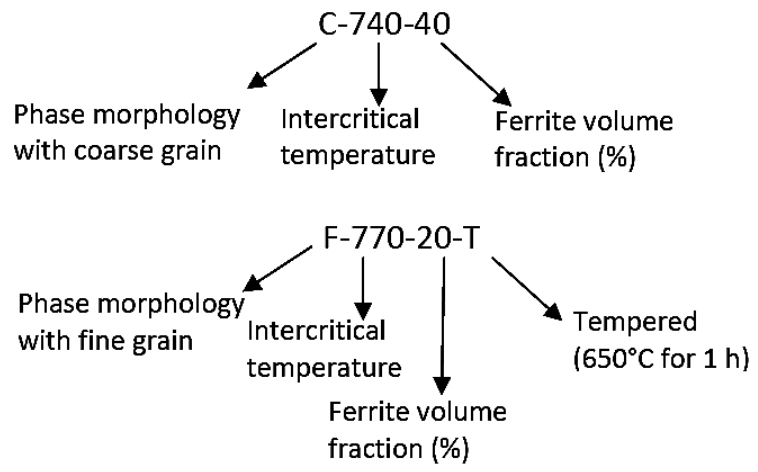

Fig. 7. Coding of experimental parameters.

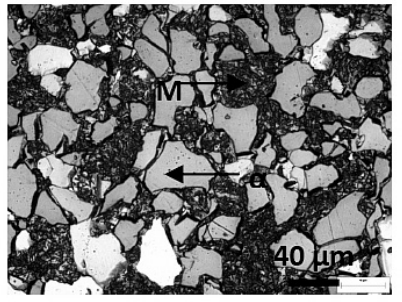

a

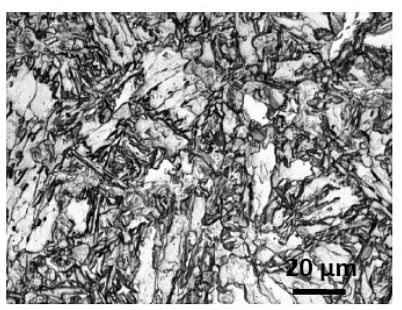

d

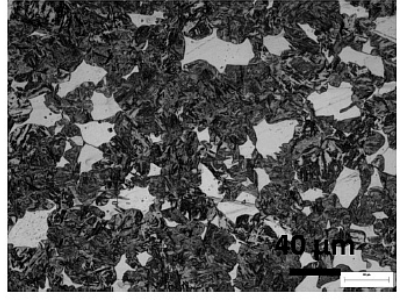

b

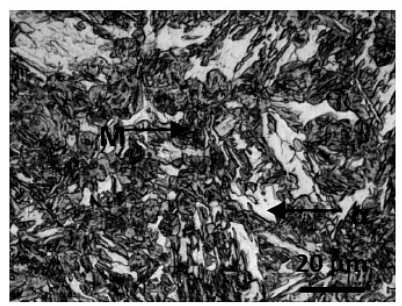

e

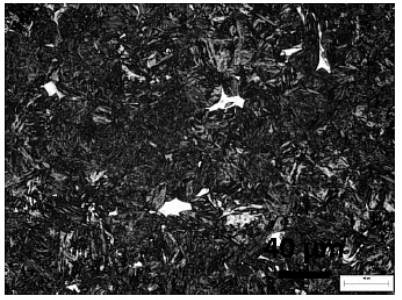

$\mathrm{c}$

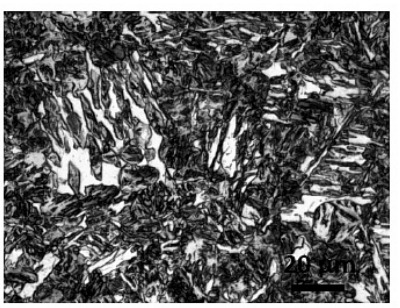

f

Fig. 8. C-740-40 (a); C-790-20 (b); C-800-10 (c); F-730-40 (d); F-770-20 (e); F-790-10 (f).

mechanical test specimens. Additionally, encoding of the specimens was conducted, as shown in Fig. 7.

Figure 8 shows the microstructures of the specimens that exhibited 40, 20, and $10 \%$ ferrite volume fractions after intercritical annealing.

Figure 9 shows the microstructures that were formed as a result of tempering the specimens shown in Fig. 8 at $650^{\circ} \mathrm{C}$ for $1 \mathrm{~h}$. 


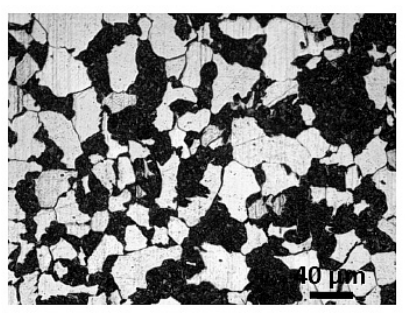

a

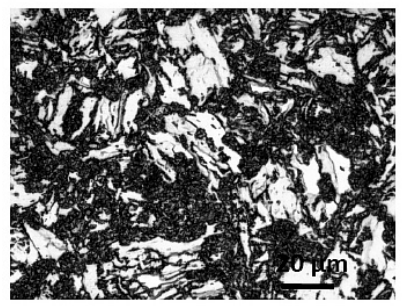

d

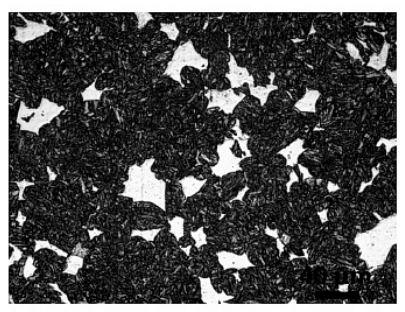

b

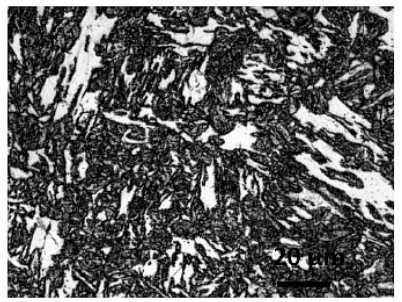

e

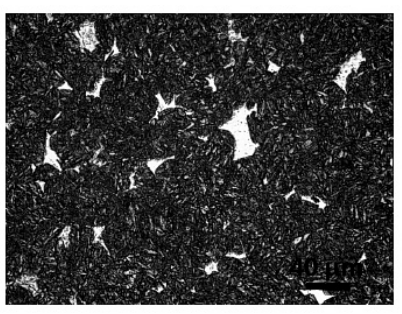

c

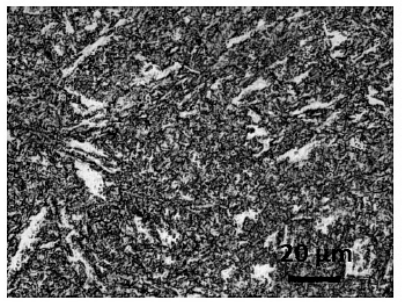

f

Fig. 9. C-740-40-T (a); C-790-20-T (b); C-800-10-T (c); F-730-40-T (d); F-770-20 (e); F-790-10-T (f).

The microstructures shown in Fig. 8 consist of ferrite and martensite. During the intercritical annealing of the microstructures with ferrite and martensite that exhibited fine grain morphologies after intercritical annealing, the austenite phase nucleated at the interfaces of the martensite plates and at the grain boundaries of the retained austenite (if any retained austenite existed). Therefore, a thin morphology may be related to the nucleation and growth of austenite in many regions due to intensive martensite plates. The microstructures obtained in the present study (Fig. 8d, e, and f) confirm the data in the literature [19-21].

Figure 9 shows that the martensite plates in the microstructures are broken up as a result of tempering. The tempered ferrite grains do not differ from the ferrite grains shown in Fig. 8. Therefore, the dispersion pattern of ferrite after intercritical annealing is almost the same as the dispersion pattern of ferrite after tempering.

2.2. Tensile Test Results. A uniaxial tensile test was conducted on three specimens for each of the experimental parameters. The arithmetic averages of the obtained results were calculated, and the results of the test are presented in Table 4. As shown in Table 4, the yield strength of the F series (fine grain) dual phase steels is generally higher than that of the $\mathrm{C}$ series (coarse grain) dual phase steels. This trend was also observed for the tempered specimens (F-T: fine tempered; C-T: coarse tempered) [1, 14, 22, 23].

The yield stress decreased with decreasing FVF. This result is due to the matrix structure of the specimens being composed of martensite rather than of ferrite. An increasing tensile strength (with decreasing FVF) was observed for both the coarse grain (C), and fine grain (F) specimens. Deformation occurred within the ferrite phase of the dual phase steels. A good deformation ability is required for ferrite to have good strength and ductility. Moreover, the existence of a compatible interface between ferrite and martensite protects the interface up to high stress levels. 
A Different Approach to the Fracture Toughness ...

$\mathrm{T}$ a b 1 e 4

Tensile Test Results of Experimental Parameters

\begin{tabular}{||c|c|c|c|c|c|c||}
\hline \hline Specimen & $\sigma_{y}, \mathrm{MPa}$ & $\sigma_{\max }, \mathrm{MPa}$ & $S_{\text {rup }}, \mathrm{MPa}$ & $\delta, \%$ & $\psi, \%$ & $d, \mu \mathrm{m}$ \\
\hline C-740-40 & 301.9 & 897.7 & 929.4 & 8.3 & 5.7 & 23.7 \\
\hline C-790-20 & 284.6 & 1313.1 & 1373.5 & 6.7 & 5.8 & 19.2 \\
\hline C-800-10 & 275.2 & 1452.7 & 1641.7 & 9.1 & 13.8 & 18.1 \\
\hline F-730-40 & 321.1 & 772.3 & 1198.4 & 16.4 & 30.8 & 6.8 \\
\hline F-770-20 & 338.1 & 1246.1 & 1390.5 & 11.3 & 14.6 & 11.3 \\
\hline F-790-10 & 298.4 & 1296.3 & 1550.7 & 10.1 & 14.5 & 10.8 \\
\hline C-740-40-T & 313.1 & 473.7 & 890.1 & 32.1 & 62.1 & 22.2 \\
\hline C-790-20-T & 466.5 & 604.4 & 1091.9 & 25.3 & 63.5 & 18.4 \\
\hline C-800-10-T & 487.2 & 617.7 & 1150.3 & 23.7 & 65.8 & 18.3 \\
\hline F-730-40-T & 410.8 & 541.9 & 1106.6 & 30.8 & 73.1 & 6.8 \\
\hline F-770-20-T & 465.1 & 600.4 & 1126.5 & 24.6 & 66.8 & 11.3 \\
\hline F-790-10-T & 507.6 & 627.9 & 1164.3 & 24.9 & 68.0 & 10.8 \\
\hline As obtained & 262.1 & 462.9 & 791.2 & 33.7 & 56.5 & 24.6 \\
\hline
\end{tabular}

When the stress is transferred from ferrite to martensite, the strength of the martensite and the compatibility of the interface cause the deformation to continue up to high stress levels without separation and therefore increase the tensile strength [24]. Another reason for the increase in tensile strength is that the martensite particle grains grow with increasing martensite volume fraction, leading to an increase in the bond length between the martensite particles and to the early transfer of the stress from ferrite to martensite before ferrite is deformed during the tensile test $[1,14,25]$. The tensile strength values of the tempered specimens were twice lower as compared with those of the specimens that were subjected to intercritical annealing. In terms of the strength values, the data obtained for the $40 \%$ FVF sample showed significant differences from those obtained for 20 and $10 \%$ FVF specimens.

The yield and tensile strength values of the tempered fine- and coarsedispersed specimens decreased with increasing FVF. However, the ductility properties did not change significantly with changing FVF. Therefore, in the present study, the tempering process optimized the mechanical properties of the dual phase steels. It was observed that the martensite plates were broken as a result of tempering and that these broken parts were homogenously distributed throughout the martensite region. As the FVF decreased, the carbides most likely dispersed into the microstructure and increased the mechanical properties of the specimens as a result of tempering.

2.3. Fracture Toughness Results. The fracture toughness of the specimens $\left(K_{\text {Ic }}\right)$ was calculated using the method described in section 2.4 and the results obtained from the uniaxial tensile test. The parameters required to obtain the fracture toughness and the results of the fracture toughness $\left(K_{\mathrm{Ic}}\right)$ values are presented in Table 5. According to formula (22), the parameters (yield stress, 
rupture strength and strain hardening coefficient) of the stress-strain diagrams, which were obtained from the tensile test, and the average grain size needs to be calculated to determine the fracture toughness $\left(K_{I c}\right)$ of the specimens. In the specimens that were subjected to intercritical annealing, it was observed that the fracture toughness $\left(K_{\mathrm{I} c}\right)$ decreased with decreasing FVF for both morphologies (fine-dispersed and coarse-dispersed).

T a b 1 e 5

Parameters Needed to Obtain the Fracture Toughness and Results of the Fracture Toughness $\left(K_{\mathrm{I} c}\right)$ Values

\begin{tabular}{|c|c|c|c|c|c|c|c|c|c|c||}
\hline Specimen & $\begin{array}{c}\sigma_{y}, \\
\mathrm{MPa}\end{array}$ & $\begin{array}{c}\sigma_{y}^{*}, \\
\mathrm{MPa}\end{array}$ & $\begin{array}{c}S_{\text {frac }}, \\
\mathrm{MPa}\end{array}$ & $\begin{array}{c}A, \\
\mathrm{MPa}\end{array}$ & $\begin{array}{c}T^{*}, \\
\mathrm{~K}\end{array}$ & $\begin{array}{c}d, \\
\mu \mathrm{m}\end{array}$ & $n$ & $\begin{array}{c}\alpha, \\
\mathrm{K}^{-1}\end{array}$ & $\begin{array}{c}\beta_{y}, \\
\mathrm{~K}\end{array}$ & $\begin{array}{c}K_{\mathrm{Ic}}^{293}, \\
\mathrm{MPa} \sqrt{\mathrm{m}}\end{array}$ \\
\hline C-740-40 & 301.9 & 298.3 & 732.3 & 1038 & 287.4 & 23.7 & 0.3405 & 0.0086 & 119.4 & 30.7 \\
\hline C-790-20 & 284.6 & 361.1 & 896.8 & 1310 & 210.4 & 19.2 & 0.5448 & 0.0096 & 127.4 & 21.5 \\
\hline C-800-10 & 275.2 & 392.0 & 976.0 & 1442 & 189.3 & 18.1 & 0.6635 & 0.0101 & 130.3 & 18.1 \\
\hline F-730-40 & 321.1 & 340.0 & 852.2 & 1148 & 250.0 & 6.8 & 0.2519 & 0.0090 & 112.5 & 44.2 \\
\hline F-770-20 & 338.1 & 360.0 & 933.8 & 1215 & 234.0 & 11.3 & 0.4171 & 0.0092 & 107.0 & 21.0 \\
\hline F-790-10 & 298.4 & 380.0 & 959.8 & 1350 & 202.8 & 10.8 & 0.5041 & 0.0098 & 120.3 & 19.4 \\
\hline C-740-40-T & 313.1 & 313.0 & 720.6 & 998 & 293.0 & 22.2 & 0.2034 & 0.0084 & 115.2 & 80.8 \\
\hline C-790-20-T & 466.5 & 466.4 & 885.0 & 895 & 293.0 & 18.4 & 0.1035 & 0.0079 & 75.1 & 114.9 \\
\hline C-800-10-T & 487.2 & 487.2 & 921.7 & 898 & 293.0 & 18.3 & 0.0898 & 0.0079 & 71.2 & 151.9 \\
\hline F-730-40-T & 410.8 & 410.7 & 864.7 & 973 & 293.0 & 10.1 & 0.1798 & 0.0082 & 87.0 & 39.2 \\
\hline F-770-20-T & 465.1 & 465.0 & 899.7 & 919 & 293.0 & 9.3 & 0.1372 & 0.0080 & 75.8 & 42.3 \\
\hline F-790-10-T & 507.6 & 507.6 & 952.3 & 952 & 293.0 & 11.3 & 0.1238 & 0.0078 & 74.1 & 52.4 \\
\hline As obtained & 262.1 & 264.2 & 655.0 & 1038 & 272.0 & 24.6 & 0.2403 & 0.0086 & 137.1 & 94.0 \\
\hline \hline
\end{tabular}

As in the case of the tensile test results, the significant impact of ferrite $(40 \%$ FVF) can be observed in the fracture toughness $\left(K_{\mathrm{Ic}}\right)$ results. The fracture toughness $\left(K_{\mathrm{I} c}\right)$ values of the $\mathrm{C}$ and $\mathrm{F}$ series of specimens with $40 \% \mathrm{FVFs}$ that were subjected to intercritical annealing were approximately 2 times higher than the fracture toughness $\left(K_{\mathrm{I} c}\right)$ values of the specimens with 20 and $10 \%$ FVFs. The effect of the tempering process on the yield and tensile stress results, which were obtained from the tensile test, can also be observed in the fracture toughness $\left(K_{\mathrm{I} c}\right)$ values. The yield stress and fracture toughness $\left(K_{\mathrm{I} c}\right)$ values of the $\mathrm{C}$ and $\mathrm{F}$ series of specimens that were subjected to intercritical annealing decreased with decreasing FVF, whereas the yield stress and fracture toughness $\left(K_{\mathrm{I} c}\right)$ values of the tempered specimens increased with decreasing FVF.

\section{Conclusions}

1. The two different starting microstructures that were obtained prior to intercritical annealing led to coarse and fine dispersions of ferrite and martensite in the microstructures. 
2. The FVF decreased with increasing intercritical annealing temperature.

3. In the specimens that were subjected to intercritical annealing, the yield strength and elongation values decreased with decreasing FVF, while the tensile strength values increased with decreasing FVF.

4. The strength and ductility properties of the fine-dispersed specimens that were subjected to intercritical annealing exhibited better results than the coarsedispersed specimens.

5. In the tempered specimens, the yield stress and tensile strength values increased with decreasing FVF; however, the elongation values did not significantly change with decreasing FVF.

6. In the specimens that were subjected to intercritical annealing, the fracture toughness $\left(K_{\mathrm{I} c}\right)$ decreased with decreasing $\mathrm{FVF}$; however, in the tempered specimens, the fracture toughness increased with decreasing FVF.

7. The highest fracture toughness value $\left(K_{\mathrm{I} c}\right)$ was obtained for the C-800-10-T specimen.

In fracture mechanics, microcracks play a large role in the damage of materials. Therefore, prevention of crack propagation is very important. In dual phase steels, the ferrite phase prevents crack propagation better than other phases. As can be observed in this study, changes in the volume fraction, the grain size and the morphology of ferrite in dual phase steels lead to changes in the fracture toughness values $\left(K_{\mathrm{I} c}\right)$ over a wide range.

\section{Резиме}

Досліджується вплив морфології структури фериту та його об'ємного вмісту на механічні властивості і в'язкість руйнування двофазних сталей. Для визначення значень в'язкості руйнування використовували не стандартний, а альтернативний підхід. Сталі піддавали гомогенізуючій термообробці. Шляхом повного відпалу або загартування сталей з аустенітного стану до використання докритичного відпалу в аустенітній області отримано дві різні початкові мікроструктури. Отримано двофазні сталі з двома типами морфології (великоі дрібнозеренна) 3 40-, 20- і 10\%-ним об'ємним вмістом фериту в залежності від початкової мікроструктури. Відпущені зразки з 10\%-ним об'ємним вмістом фериту мали більш високі значення в'язкості руйнування порівняно 3 такими інших зразків із цих сталей.

1. R. G. Davies, "Influence of martensite composition and content on the properties of dual-phase steels," Metall. Trans., 9A, 671-679 (1978).

2. G. R. Speich, "Dual phase steels," in: ASM Handbook, Vol. 1: Properties and Selection: Irons, Steels, and High-Performance Alloys, ASM International (1990), pp. 424-429.

3. K. V. Sudhakar and E. S. Dwarakadasa, "A study on fatigue crack growth in dual phase martensitic steel in air environment," Bull. Mater. Sci., 23, No. 3, 193-199 (2000).

4. Y. J. Chao, J. D. Ward and R. G. Sands, "Charpy impact energy, fracture toughness and ductile-brittle transition temperature of dual-phase 590 steel," Mater. Design, 28, No. 2, 551-557 (2007). 
5. ASTM E-399. Test Method for Linear-Elastic Plane-Strain Fracture Toughness $K_{\mathrm{Ic}}$ of Metallic Materials, Annual Book of ASTM Standards, Vol. 03.01 (2003).

6. K. W. Andrews, "Empirical formulae for the calculation of some transformation temperatures," J. Iron Steel Inst., 203, 721-727 (1965).

7. ASTM E8-01. Test Methods for Tension Testing of Metallic Materials, Annual Book of ASTM Standards, Vol. 03.01 (2003).

8. G. I. Saidov, "A thermal activation approach to the crack resistance of steels," Fatigue Fract. Eng. Mater. Struct., 20, Issue 1, 41-47 (1997).

9. N. A. Makhutov, Resistance of Constructional Components Against Brittle Fracture [in Russian], Mashinostroenie, Moscow (1973).

10. V. D. Yaroshevich and D. G. Rivkina, "On thermoactivated character of plastic deformation of metals," Fiz. Tverd. Tela, 12, No. 2, 68-77 (1970).

11. L. A. Kopelman, Resistance of Weld Joints to Brittle Fracture [in Russian], Mashinostroenie, Leningrad (1978).

12. G. Said and S. Tasgetiren, "Fracture toughness determination of low-alloy steels by thermoactivation energy method," Eng. Fract. Mech., 67, No. 4, 345-356 (2000).

13. A. Y. Krasowsky, "Characteristic distance as a material's structure parameter in the theory of fracture emanating from notches and cracks," in: G. Pluvinage and M. Gjonaj (Eds.), Notch Effects in Fatigue and Fracture, Kluwer Academic Publishers, Dordrecht (2001), pp. 23-38.

14. N. J. Kim and G. Thomas, "Effects of morphology on the mechanical behavior of a dual-phase Fe/2Si/0.1C steel," Metall. Trans., 12A, 483-489 (1981).

15. D. J. Hillis, D. T. Llewellyn, and P. J. Evans, "Rapid annealing of dual-phase steels," Ironmaking \& Steelmaking, 25, No. 1, 47-54 (1998).

16. R. Priestner and M. Ajmal, "Effect of carbon content and microalloying on martensitic hardenability of austenite of dual phase steels," Mater. Sci. Technol., 3, 360-364 (1987).

17. R. Priestner, "Effect of austenite dispersion and plastic deformation on phase transformation in dual phase steel," in: Conf. Proc. Phase Transformation'87, Instute of Metals, Cambridge (1987), pp. 411-413.

18. M. Erdogan, "Effect of austenite dispersion on phase transformation in dual phase steel," Scripta Mater., 48, No. 5, 501-506 (2003).

19. L. Giordano, P. Matteazzi, A. Tiziani, and A. Zambon, "Retained austenite variation in dual-phase steel after mechanical stressing and heat treatment," Mater. Sci. Eng. Struct., 131A, Issue 2, 215-219 (1991).

20. D. Z. Yang, E. L. Brown, D. K. Matlock, and G. Krauss, "The formation of austenite at low intercritical annealing temperatures in a normalized $0.08 \mathrm{C}-$ 1.45Mn-0.21Si steel," Metall. Mater. Trans., 16A, No. 8, 1523-1526 (1985).

21. W. C. Jeong and C. H. Kim, "Ferrite growth on cooling after intercritical annealing in a dual phase steel," Scripta Metall., 19, Issue 1, 37-42 (1985). 
22. M. Erdogan, Bauschinger and Tensile Properties of Dual-Phase Steels, Ph.D. Thesis, The Manchester University, UK (1993).

23. Y. Tomita, "Effect of morphology of second-phase martensite on tensile properties of Fe-0.1C dual-phase steels," J. Mater. Sci., 25, Issue 12, 51795184 (1990).

24. G. R. Speich, V. A. Demarest, and R. L. Miller, "Formation of austenite during intercritical annealing of dual-phase steels," Metall. Mater. Trans., 12A, 1419-1428 (1981).

25. R. G. Davies and C. I. Magee, "Physical metallurgy of automotive high strength steels," in: R. A. Kot and J. W. Morris (Eds.), Structure and Properties of Dual-Phase Steels, AIME (1979), pp. 1-19.

Received 02. 02. 2013 